\title{
A DdeI polymorphism in the growth hormone gene is associated with higher lean meat yield and pH 45 min in postmortem pigs
}

\author{
I.M. Ferreira ${ }^{1}$, T.F. Braga ${ }^{1}$, E.C. Guimarães ${ }^{1,4}$, M.C. Durval ${ }^{2}$, \\ L.B. Mendes ${ }^{2}$, J.S. Soares ${ }^{1}$, D.L. Matarim ${ }^{1}$, B.C. Kruger ${ }^{1}$, \\ M.M. Franco ${ }^{3,4}$ and R.C. Antunes ${ }^{1,4}$ \\ ${ }^{1}$ Programa de Pós-graduação em Ciências Veterinárias, Uberlândia, MG, \\ Brasil \\ ${ }^{2}$ Graduação em Medicina Veterinária, Uberlândia, MG, Brasil \\ ${ }^{3}$ Embrapa Recursos Genéticos e Biotecnologia, Brasília, DF, Brasil \\ ${ }^{4}$ Universidade Federal de Uberlândia, Uberlândia, MG, Brasil \\ Corresponding author: I.M. Ferreira \\ E-mail: isaura@iftm.edu.br \\ Genet. Mol. Res. 18 (2): gmr18257 \\ Received February 08, 2019 \\ Accepted May 17, 2019 \\ Published May 24, 2019 \\ DOI http://dx.doi.org/10.4238/gmr18257
}

ABSTRACT. Marker-assisted selection has been widely used in breeding programs. The use of single nucleotide polymorphisms (SNPs) as genetic markers enables identification of genotypes that best contribute to quantitative characteristics. We evaluated a possible association between the DdeI growth hormone gene polymorphism and meat and carcass traits. A total of 476 halothanefree animals were genotyped. Animals originated from the crossing of an AGIPIC 415 male with Large White (LW) x Landrace (LD) females. Males were castrated when young and males and females were slaughtered between 150 and 180 days old. Hot carcass weight, carcass length, $\mathrm{pH} 45$ min, and $\mathrm{pH} 16$ postmortem of Longissimus cervicis, Longissimus dorsi, and Semimembranosus muscles, backfat thickness, Longissimus dorsi muscle depth, and color by the CIELAB system were measured and the percentage of lean meat was calculated. Water holding capacity was determined by the filter paper method in the Semimembranosus muscle. A 605-base pair (bp) 
amplicon was obtained by PCR and a DdeI polymorphism was genotyped and two alleles identified, D1 with 335, 148, and $122 \mathrm{bp}$ and D2 allele with 457 and $148 \mathrm{bp}$. Allele frequencies were 0.43 for D1 and 0.57 for D2. Genotypic frequencies were as follows: D1D1 (22.1\%), D1D2 (49.8\%), and D2D2 (28.1\%). The Chi-Square test showed that the population was in Hardy-Weinberg equilibrium. The results of hot carcass weight, carcass length, $\mathrm{pH} 16$ postmortem of Longissimus cervicis, Longissimus dorsi, and Semimembranosus muscles, backfat thickness, Longissimus dorsi muscle depth, color and water holding capacity did not differ significantly among the genotypes. The DdeI SNP was associated with lean meat percentage and $\mathrm{pH}$ at 45 min posmortem in the Longissimus cervicis muscle; properties that are important for the commercialization of fresh meat as well as processed products.

Key words: Single nucleotide polymorphism; Growth Hormone; Carcass traits; Meat quality; Swine

\section{INTRODUCTION}

Analysis of pork quality considers cultural, sensorial, nutritional, and hygienic properties, economic issues, improvement in ante and postmortem handling, technological processes, and genetic variables (Rosenvald and Andersen, 2003; Joo et al., 2013; Pena et al., 2016). However, to meet the need for increased production and improve carcass and meat quality, producers and the swine processing industry have begun using molecular techniques. With the information obtained by DNA analyses, it is possible to select genes that significantly affect production, enabling the use of marker-assisted selection (Samarai and Al-Kazaz, 2015; Pena et al., 2016). Many genes known to affect carcass and meat quality have been mapped in swine, among which porcine growth hormone (pGH) is especially important.

pGH has more than 300 functions (Waters et al., 2006); it is involved in the growth of skeletal muscles, bone, and adipose tissue (Parr et al., 2016; Lan et al., 2018) and stimulates the production of insulin-like growth factor 1 in the liver (Cheng et al., 2016). Studies to improve meat quality and performance characteristics with variants of the pGH gene were described by Schellander et al. (1994); Knorr et al. (1997); Cheng et al. (2000); Song et al. (2003); Franco et al. (2008); Bižiené et al. (2011); and Lyubov et al. (2016).

The allelic frequencies of pGH polymorphism between breeds may not be the same, because these populations undergo different selection pressures, for distinct characteristics, such as carcass quality and meat. 'For example, Wenjun et al. (2003) found that European breeds had high B allele frequencies, whereas Chinese native breeds showed high frequencies of the A allele for the ApaI in a study of pGH gene polymorphism. Franco et al. (2005) observed that the D1D2 genotype was associated with a higher percentage of lean meat and lower backfat thickness in a Landrace swine population. Carcass length was related to the $\mathrm{pGH} / \mathrm{DdeI}$ polymorphism in Large White 
swine (Putnová et al., 2001). However, Rybarczyk et al. (2007) observed no relationship between the identified pGH genotypes with the MspI, HaeII, CfoI, and ApaI enzymes with carcass and meat quality. Additionally, Casas-Carrillo et al. (1997) did not detect an association between $\mathrm{pGH} / \mathrm{DdeI}$ and $\mathrm{pGH} / \mathrm{HaeII}$ gene polymorphisms with carcass and meat quality determined based on $\mathrm{pH}$.

The aim of this study was to evaluate the association between the DdeI polymorphism in the pGH gene with meat quality and carcass traits in a crossbred population of pigs.

\section{MATERIAL AND METHODS}

\section{Samples}

A total of 476 left half carcasses from 150 to 180 days-old female and castrated male pigs from a commercial cross (AGIPIC 415 males $\times$ LW and LD females) were used. All animals were halothane-free and were raised under the same conditions and from two commercial farms. Animals were shipped and transported in accordance with animal welfare standards and slaughtered in a local slaughterhouse according to the Brazilian legislation.

\section{Carcass traits and meat quality}

Temperature and $\mathrm{pH}$ were measured at two time points $(45 \mathrm{~min}$ and $16 \pm 3 \mathrm{~h}$ postmortem) in the Semimembranosus (SM), Longissimus dorsi (LD), and Longissimus cervicis (LC) muscles using a portable $\mathrm{pH}$ meter (model 205, brand Testo, West Chester, PA, USA) with digital identification and automatic temperature compensation. Carcass length (CL) was measured in the still hot half carcasses, considering as the initial point of measurement the ventral skull edge of the Atlas and end point the cranial edge of the pubic symphysis, according to the Brazilian carcass evaluation method (ABCS, 1973), using a precision measuring tape with $0.05 \mathrm{~cm}$ increments. Data of color was obtained on the SM and LC muscles using the Delta Vista ${ }^{\circledR}$ portable spectrophotometer (GE Healthcare, Little Chalfont, UK) at $16 \pm 3 \mathrm{~h}$ postmortem, where $\mathrm{L}^{*}$ corresponds to the flesh luminosity, $\mathrm{a}^{*}$ to the red content, and $\mathrm{b}^{*}$ to the yellow content, according to the CIELAB system. Weight of the hot carcass was obtained before being placed in the cold chamber and the cold weight was determined after 16 \pm 3 Backfat thickness (BT) was measured between the last lumbar vertebra and first sacral vertebra in the median sagittal plane using a caliper. The Longissimus dorsi depth (LDD) and backfat depth (BD) were determined at the last lumbar vertebra, perpendicularly to the dorsal-lumbar line, at $6 \mathrm{~cm}$ from the vertebral column with a caliper. All measurements were performed on cold carcass. To calculate the percentage of lean meat (LM), the equation described by Antunes was used (2018), as follow: Lean meat yield $(\%)=67,31240-0,47691 \times$ backfat thickness

The water holding capacity (WHC) was measured using a modified compression method described by Grau and Hamm (1953) in the Semimembranosus 
muscle. This procedure was performed in duplicate. Next, the liquid and meat areas were photographed and processed with the ImageJ $1.8^{\circledR}$ image analysis tool $(\mathrm{NIH}$, Bethesda, MD, USA). The WHC was expressed as the ratio of the compressed area of the meat divided by the exudate area in the filter paper.

\section{Molecular analyses}

Samples of the SM muscle were collected and stored in sterile plastic tubes at $80^{\circ} \mathrm{C}$ until processing. To isolate the genomic DNA, the PureLink ${ }^{\circledR}$ Genomic Kit (Invitrogen, Carlsbad, CA, USA) was used according to the manufacturer's recommendations. The NanoDrop ${ }^{\circledR}$ ND-1000 spectrophotometer (Waltham, MA, USA) was used for DNA quantification. For genotyping, a pair of primers was used (forward 5' TTATCCATTAGCACATGCCTGCCAG $3^{\prime}$ and the reverse 5' CTGGGGAGTTACAAACTCCTT 3' (Genbank Accession number: M17704)), as designed by Larsen and Nielsen (1993) to amplify a region of $605 \mathrm{bp}$. PCR was performed in a final volume of $20 \mu \mathrm{L}$. Each reaction contained the following: $1 \mathrm{X}$ buffer, $2 \mathrm{mM}$ of $\mathrm{MgCl} 2,0.4 \mathrm{mM}$ dNTPs, $7.5 \times 10^{-6} \mu \mathrm{M}$ each primer (forward and reverse), $1 \mathrm{U}$ of Taq polymerase, genomic DNA (50 - $200 \mathrm{ng}$ ), and ultrapure water to the final volume. The thermocycler conditions were as follows: initial denaturation at $95^{\circ} \mathrm{C}$ for $3 \mathrm{~min}, 35$ cycles at $95^{\circ} \mathrm{C}$ for $45 \mathrm{~s}, 61^{\circ} \mathrm{C}$ for $40 \mathrm{~s}, 76^{\circ} \mathrm{C}$ for $1 \mathrm{~min}$, and final extension at $76^{\circ} \mathrm{C}$ for $4 \mathrm{~min}$. After amplification, $5 \mu \mathrm{L}$ of the PCR product was added to $2 \mu \mathrm{L}$ of loading buffer and applied to a $2.0 \%$ agarose gel for electrophoresis. The amplicon of 605-bp of length was confirmed under UV light and photodocumented. The remaining $15 \mu \mathrm{L}$ was digested with $3 \mathrm{U}$ of the restriction enzyme DdeI overnight at $37^{\circ} \mathrm{C}$. After digestion, $3 \mu \mathrm{L}$ of loading buffer was added to each sample and applied to a $2.5 \%$ agarose gel and stained with ethidium bromide, which was visualized under UV light and photodocumented. For the GH gene after digestion of the samples, two alleles were obtained: D1 with fragments of 335, 148, and 122 bp and D2 with 457 and 148 bp.

\section{Statistical analysis}

Allele frequencies were calculated by simple allele counting (Falconer; Mackay, 2012).Chi-square test was used to determine if the frequencies were in Hardy-Weinberg equilibrium. To test the association between genotypes and carcass and meat quality traits, the partial quantile covariate was used; analysis of equality of variances by the Levene test and a normality test of the residues in the analysis of variance mathematical model were performed. Considering that data do not show normality, the Kruskal Wallis test was performed. Farm was initially considered in the statistical model, but as the result was not significant, it was removed as an effect in the analysis. The data were analyzed using SPSS software (SPSS, Inc., Chicago, IL, USA). 


\section{RESULTS}

DdeI restriction enzyme digestion of the 605-bp PCR amplicon revealed two alleles: $D 1(335,148$, and 122 bp) and $D 2$ (457 and 148 bp) (Figure 1).

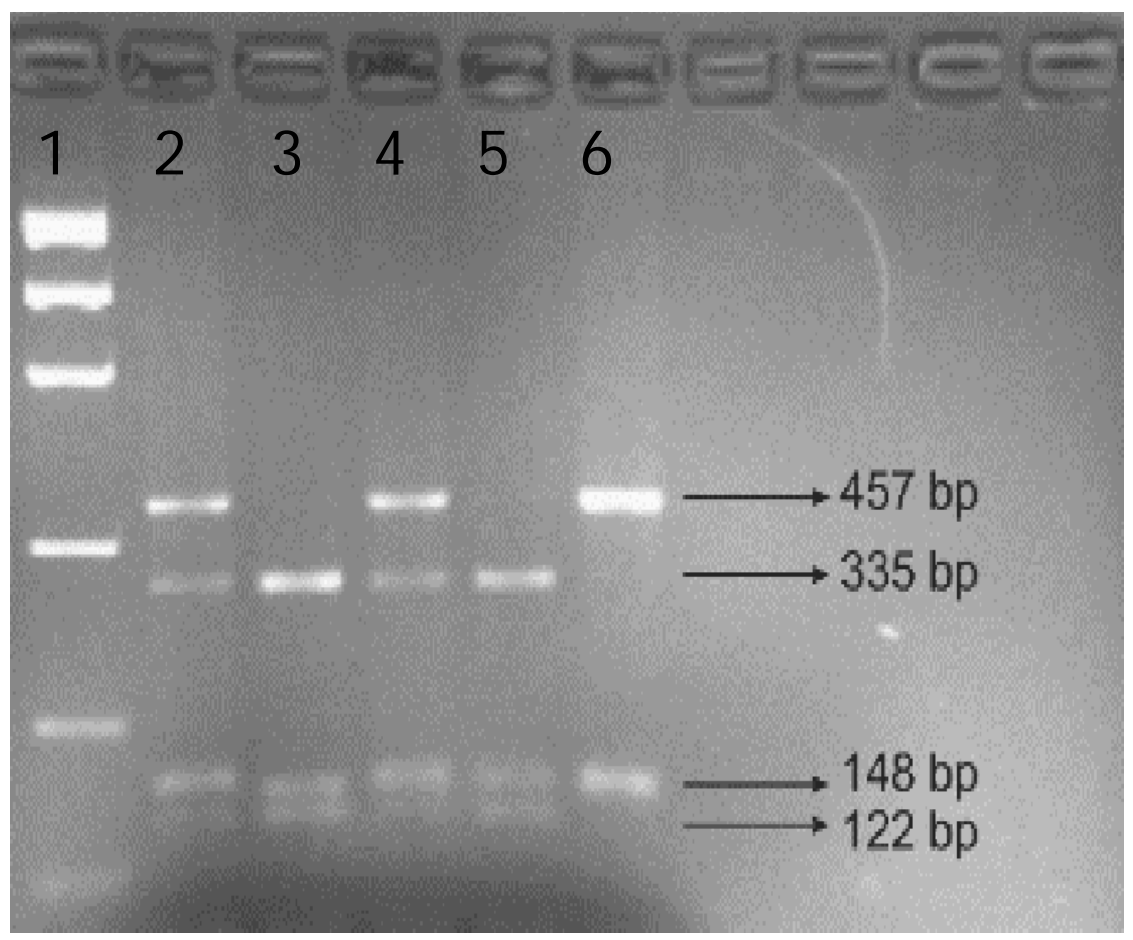

Figure 1. DdeI polymorphism in the growth hormone gene detected by PCR-RFLP. PCR products were run in a 2.5\% agarose gel. Lane 1: $1 \mathrm{~Kb}$ DNA ladder (Invitrogen); lanes 2 and 4: $\mathrm{D}_{1} \mathrm{D}_{2}$, genotype lanes 3 and 5: genotype: $\mathrm{D}_{1} \mathrm{D}_{1}$ genotype and lane $6 \mathrm{D}_{2} \mathrm{D}_{2}$ genotype. bp - base pairs.

Table 1 shows genotypic and allelic frequencies of Gh DdeI polymorphism. Chi-square test $\left(\chi^{2}=4.97 ; \mathrm{P}<0.05\right)$ indicated that the observed and expected frequencies of the $\mathrm{pGH} / \mathrm{DdeI}$ genotypes were in Hardy-Weinberg equilibrium.

Table 1. Genotypic and allelic frequencies of the DdeI pGH gene polymorphism.

\begin{tabular}{lllllc}
\hline Genotype pGH /DdeI & $\begin{array}{l}\text { Observed } \\
\text { Frequency (\%) }\end{array}$ & $\begin{array}{l}\text { Observed } \\
\text { Frequency (\%) }\end{array}$ & $\begin{array}{l}\text { Expected Frequency } \\
(\boldsymbol{\%})\end{array}$ & ${\text { Allele } \mathbf{D}_{\mathbf{1}}(\boldsymbol{\%})}^{\text {Allele } \mathbf{D}_{\mathbf{2}}(\boldsymbol{\%})}$ \\
\hline $\mathrm{D}_{1} \mathrm{D}_{1}$ & 93 & 19.5 & 22.1 & & \\
$\mathrm{D}_{1} \mathrm{D}_{2}$ & 262 & 54.8 & 49.8 & 47 & 53 \\
$\mathrm{D}_{2} \mathrm{D}_{2}$ & 122 & 25.0 & 28.1 & & \\
\hline
\end{tabular}

Data on meat quality and carcass traits according to the genotypic effect of the pGH/DdeI gene are shown in Table 2. 


\begin{tabular}{|c|c|c|c|c|c|c|}
\hline & D1D1 & & D1D2 & & D2D2 & \\
\hline Variables & Mean & SD & Mean & SD & Mean & SD \\
\hline $\mathrm{HCW}$ & $79.72^{\mathrm{a}}$ & 11.2 & $83.27^{\mathrm{a}}$ & 10.66 & $82.12^{\mathrm{a}}$ & 10.87 \\
\hline$\%$ LM & $61.60^{\mathrm{a}}$ & 2.78 & $62.80^{\mathrm{a}}$ & 2.24 & $63.13^{\mathrm{b}}$ & 2.34 \\
\hline $\mathrm{CL}(\mathrm{cm})$ & $93.70^{\mathrm{a}}$ & 4.38 & $94.63^{\mathrm{ab}}$ & 3.89 & $94.16^{\mathrm{a}}$ & 4.73 \\
\hline $\mathrm{BT}(\mathrm{mm})$ & $8.95^{\mathrm{a}}$ & 4.80 & $10.14^{\mathrm{a}}$ & 5.15 & $9.52^{\mathrm{a}}$ & 5.25 \\
\hline $\mathrm{BD}(\mathrm{mm})$ & $18.65^{\mathrm{a}}$ & 6.48 & $19.41^{\mathrm{a}}$ & 6.14 & $18.10^{\mathrm{a}}$ & 7.47 \\
\hline $\mathrm{pH} 45 \mathrm{LC}$ & $6.51^{\mathrm{a}}$ & 0.25 & $6.45^{\mathrm{ab}}$ & 0.26 & $6.43^{\mathrm{b}}$ & 0.26 \\
\hline $\mathrm{pH} 45 \mathrm{LD}$ & $6.63^{\mathrm{a}}$ & 0.26 & $6.60^{\mathrm{a}}$ & 0.31 & $6.60^{\mathrm{a}}$ & 0.33 \\
\hline pH45 SM & $6.59^{\mathrm{a}}$ & 0.49 & $6.62^{\mathrm{a}}$ & 0.31 & $6.63^{\mathrm{a}}$ & 0.31 \\
\hline${ }^{\circ} \mathrm{C} 45^{\prime}-\mathrm{LD}$ & $31.43^{\mathrm{a}}$ & 4.17 & $31.33^{\mathrm{a}}$ & 4.04 & $31.85^{\mathrm{a}}$ & 31.85 \\
\hline $\mathrm{CCW}$ & $77.72^{\mathrm{a}}$ & 10.9 & $81.1^{\mathrm{a}}$ & 10.43 & $80.07^{\mathrm{a}}$ & 10.63 \\
\hline $\mathrm{pH} \pm 16-\mathrm{LC}$ & $6.42^{\mathrm{a}}$ & 0.54 & $6.40^{\mathrm{a}}$ & 0.66 & $6.51^{\mathrm{a}}$ & 0.48 \\
\hline $\mathrm{pH} \pm 16 \mathrm{LD}$ & $6.20^{\mathrm{a}}$ & 0.50 & $6.14^{\mathrm{a}}$ & 0.56 & $6.74^{\mathrm{a}}$ & 5.99 \\
\hline $\mathrm{pH} \pm 16 \mathrm{SM}$ & $5.93^{\mathrm{a}}$ & 0.70 & $5.96^{\mathrm{a}}$ & 0.62 & $6.01^{\mathrm{a}}$ & 0.48 \\
\hline LDD & $65.82^{\mathrm{a}}$ & 14.18 & $66.66^{\mathrm{a}}$ & 10.70 & $66.82^{\mathrm{a}}$ & 11.25 \\
\hline WHC-SM & $0.40^{\mathrm{a}}$ & 0.08 & $0.41^{\mathrm{a}}$ & 0.09 & $0.40^{\mathrm{a}}$ & 0.09 \\
\hline $\mathrm{L}^{*} \mathrm{SM}$ & $38.29^{\mathrm{a}}$ & 11.15 & $38.16^{\mathrm{a}}$ & 8.00 & $38.74^{\mathrm{a}}$ & 5.39 \\
\hline Color a* SM & $-2.22^{\mathrm{a}}$ & 1.76 & $-2.00^{\mathrm{a}}$ & 2.16 & $-2.09^{a}$ & 1.99 \\
\hline Color $\mathrm{b}^{*}-\mathrm{SM}$ & $5.74^{\mathrm{a}}$ & 2.43 & $5.30^{\mathrm{a}}$ & 1.79 & $5.33^{\mathrm{a}}$ & 2.31 \\
\hline \multicolumn{7}{|c|}{$\begin{array}{l}\text { SD - Standard deviation, LC - Longissimus cervicis, HCW- hot carcass weight, LM - lean meat, CL - carcass length, LD } \\
\text { - Longissimus dorsi, CCW - cold carcass weight, SM - Semimembranosus muscle, LDD - Longissimus dorsi depth, BT - } \\
\text { backfat thickness, BD - backfat thickness, WHC - water holding capacity, L* - luminosity. Different letters in the same } \\
\text { line indicate a significant difference }(\mathrm{P}<0.05) \text { by the Kruskal Wallis test. }\end{array}$} \\
\hline
\end{tabular}

\section{DISCUSSION}

Based on the $\chi^{2}$ test, the population was found to be in Hardy-Weinberg equilibrium, showing allelic frequencies of D1 (0.47) and D2 (0.53), demonstrating that in this population, this polymorphism can be used as a selection tool. Franco et al. (2001), identified the allelic and genotypic frequencies for the DdeI polymorphism in the GH gene showing allelic frequencies for Landrace (D1: 0.69 and D2: 0.31), Large White (D1: 0.25 and D2: 0.75) and Pietrain (D1: 0.72 and D2: 0.28). It is interesting to note that the frequencies of the Pietrain and Landrace breeds are close, suggesting that they may be selected for the same characteristics. Demonstrating that the genotypic frequencies of these populations were influenced by the selection of quantitative characteristics.

Kaushik et al. (2014), studying the DdeI polymorphism, found both D1 and D2 alleles. The D1 allele was most frequent in Hampshire (0.55), while D2 was found in the between Hampshire $\times$ Ghungroo (0.6) cross.

When the GH genotypes were evaluated in this work, differences were found for lean meat characteristics, with the D2D2 genotype presenting the highest percentage. Franco et al. (2008) who concluded that there is a direct effect of the D2 allele (GH / DdeI) on pork quality. The trend toward lean meat consumption has increased the selection of animals for this characteristic.

Regarding pH45 we showed that the D2D2 animals had a lower value than the others, Kauffman (Kauffman, 1991; Ramos et al., 2009) However, pH at 45 min is not a good indicator of the final quality of the meat according to Kauffman (1991) and 
Tomovic et al (2014), pH45 <6 may be an indicator of pale, soft, and exudative meat and values above 6.3 are desirable for obtaining reddish, firm, non-exudative meat in the case of loin and leg muscles, which predominantly contain white fibers. However, the LC muscle consists predominantly of red fibers, which are an indicator of dark, firm, and dry (DFD) meat. Variations of $\mathrm{pH} 45$ have multifactorial causes such as the hottest season of the year, fights between animals that did not fast, and type of muscular fiber (Dalla Costa et al., 2016; Rey-Salgueiro et al., 2018). Due to these factors, the $\mathrm{pH}$ decline in the transformation of muscle into meat directly influences attributes such as color, WHC, softness, and flavor, according to Rübensam (2000), Ramos; Gomide (2007), and Scheffler et al. (2013); thus meat should not be classified using a single parameter. Meat, which can also be classified by the WHC as pale, soft, and exudative or as DFD, was analyzed in this study using the filter paper method for the SM muscle, which revealed no significant difference among genotypes considered normal for the muscles (Houfmann, 1982). Using the same method, Tomovic et al. (2014) showed that for the Landrace and Large White breeds WHC is influenced by the muscle type. WHC is an important attribute in the industry, as it affects the yield of processed fresh meat products.

The color of pork is influenced by multiple factors, such as feed, pre-slaughter handling, genetics, age, anatomical function of the muscle, amount of oxidative and glycolytic metabolism, mixed fibers, and sex (Kim et al., 2013; Arkfeld et al. 2017; Faucitano, 2018). A study of the color of muscles showed that the SM muscle of castrated males and females produced under the same conditions did not show differences in $\mathrm{L}^{*}, \mathrm{a}^{*}$, and $\mathrm{b}^{*}$, indicating no effect of sex (Overholt et al., 2016).

Some studies observed an association between variants in the pGH gene with meat quality attributes (Putnová, et al., 2001; Faria et al., 2006; Bižienė et al., 2011; Lyubov, et al., 2016). Rybarczyk et al. (2007), studying four SNPs, and Kmiec et al. (2010), evaluating the HaeII polymorphism, observed that this association was weak or non-existent for the characteristics associated with meat quality. Bižienè et al. (2018), investigated SNPs in 143 animals of five different breeds and found that GH polymorphism (M17704.1: g.316G>A) is significant for daily weight gain; the highest value was found for $\mathrm{CC}$ genotype pigs. They also suggested that this ranking is due to differences between races.

Balatisky et al. (2015) suggested that using pGH as a molecular marker in assisted selection is effective only in some populations. The differences are related both to the peculiarities of their specialization in genetic improvement as related to productivity and origin, due to the number of QTLs.

\section{CONCLUSIONS}

The polymorphism of the pGH / DdeI gene was related to the characteristics of lean meat and $\mathrm{pH}$ at 45 minutes, properties that are important for the commercialization of fresh meat as well as processed products. 


\title{
ACKNOWLEDGMENTS
}

The authors thank Embrapa Genetic Resources \& Biotechnology and the São Pedro Slaughterhousefor their help.

\section{CONFLICTS OF INTEREST}

\author{
The authors declare no conflict of interest.
}

\section{REFERENCES}

ABCS (Associação Brasileira dos Criadores de Suínos). (1973). Métodos brasileiros de classificação de carcaças. 2. ed. Rio Grande do Sul: Estrela. 17 p.

Al-Samarai FR and Al-Kazaz AA (2015). Applications of Molecular markers a in animal breeding: a review. Am. $J$. Appl. Sci. Res. 1(1): 1-15. http//:doi:10.11648/j.ajasr.20150101.11.

Antunes RC (2018). Efeitos das linhas maternas e paternas e do genótipo Hal em Suínos. 1. ed. Beau Bassin: Novas Edições Acadêmicas.

Arkfeld EK, Mohrhauser DA, King DA, Wheeler TL, et al. (2017). Characterization of variability in pork carcass composition and primal quality. J. Anim. Sci. 95: 697-708. https://doi:10.2527/jas.2016.1097

Balatsky VN, Saienko AM, Pena RN, Buslyk TV, et al. (2015). Genetic diversity of pig breeds on ten production quantitative traits loci. Cytol. Genet. 49(5): 299-307. https://doi.org/10.3103/S0095452715050023

Bižienė R, Miceikienè I, Baltrènaite L and Krasnopiorova N (2011). Association between growth hormone gene polymorphism and economic traits in pigs. Vet. Med. Zoot. 56: 56-78.

Bižienè R, Morkūnienė K, Mišeikienè R, Pečiulaitienė N, et al. (2018). Effects of single nucleotide polymorphism markers on the carcass and fattening traits in different pig populations. J. Anim. Feed Sci. 27: 255-262. https://doi.org/10.22358/jafs/95020/2018

Casas-Carrillo E, Kirkpatrick BW, Prill-Adams A, Price SG, et al. (1997). Relationship of growth hormone and insulin-like growth factor-1 genotypes with growth and carcass traits in swine. Anim. Genet. 28: 88-93.

Cheng WT, Lee CH, Hung CM, Chang TJ, et al. (2000). Growth hormone gene polymorphisms and growth performance traits in Duroc, Landrace and Tao-Yuan pigs. Theriogenology. 54: 1225-1237. http://doi.org/10.1016/S0093-691X (00)00429-5

Cheng Y, Liu S, Su D, Lu C, et al. (2016). Distribution and linkage disequilibrium analysis of polymorphisms of GH1 gene in different populations of pigs associated with body size. J. Genet. 95: 79-87. http://doi.10.1007/s12041-0150611-0

Dalla Costa FA, Devillers N, Paranhos da Costa MJR, et al. (2016). Effects of applying preslaughter feed withdrawal at the abattoir on behaviour, blood parameters and meat quality in pigs. Meat Sci. 119: 89-94. http/: doi: 10.1016/j.meatsci.2016.03.033

Falconer DS and Mackay TFC (1996). Introduction to quantitative genetics. Harlow: Longman, Scientific\&Technical, $464 \mathrm{p}$.

Faria DA, Guimaraes SEF, Lopes OS, Pires AV, et al. (2006). Association between G316A growth hormone polymorphism and economic traits in pigs. Genet. Mol. Biol. 29: 634-640.

Faucitano LJ (2018). Preslaughter handling practices and their effects on animal welfare and pork quality. J. Anim. Sci. 96: 728-738. http:// doi: 10.1093/jas/skx064

Franco MM, Santana BAA, Goulart Filho LR, Antunes RC, et al. (2001). Determination of polymorphisms in the growth of the hormone gene in three populations of pigs. Cienc. Rural 3: 329-331. https://doi.org/10.1590/S010384782001000200023

Franco MM, Antunes RC, Borges M, Melo EO, et al. (2008). Influence of breed, sex and growth hormone and halothane genotypes on carcass composition and meat quality traits in pigs. J. Muscle Foods. 19: 34-49. https://doi.org/10.1111/j.1745-4573.2007.00098.x

Franco MM, Antunes RC, Silva HD and Goulart LR (2005). Association of PIT1, GH and GHRH polymorphisms with performance and carcass traits in Landrace pigs. J. Appl. Genet. 46: 195-200.

Grau R, Hamm R (1953). Eine Einfache Methode zur Bestimmung der Wasserbindung im Fleisch. Fleischwirtschaft. 4: 295-297.

Hofmann K, Hamm R and Bluchel E (1982). Neus über die Bestimung der Wasserbindung im Fleisch. Fleischwirtschaft. 62: 346.

Joo ST, Kim GD, Hwang HY and Ryu YC (2013). Control of fresh meat quality through manipulation of muscle fiber characteristics. Meat Sci. 95: 828-836. https://doi.org/10. 1016/j.meatsci.2013.04.044

Genetics and Molecular Research 18 (2): gmr18257

CFUNPEC-RP www.funpecrp.com.br 
Kauffman RG (1991). Electronic evaluation of meat quality. In: Proceedings of the symposium Electronic Evaluation of Meat in Support of Value-based Marketing, 27-28 March 1991, Indiana. Indiana: Purdue University. pp. 199-221.

Kaushik P, Naskar S, Handique PJ, Rahman H, et al. (2014). Molecular characterization of growth hormone gene in exotic and crossbred pigs. Int. J. Adv. Technol. Eng. Sci. 2: 519-521.

Kim GD, Ryu YC, Jeong JY, Yang HS, et al. (2013). Relationship between pork quality and characteristics of muscle fibers classified by the distribution of myosin heavy chain isoforms. Anim. Sci. 91: 5525-5534. http//: doi: $10.2527 /$ jas.2013-6614.

Knorr C, Moser G, Müller E and Geldermann H (1997). Associations of GH gene variants with performance traits in F2 generations of European wild boar, Piétrain and Meishan pigs. Anim. Genet. 28: 124-128.

Kmiec M, Kocwin-Podsiadla M, Terman A, Krzecio E, et al. (2010). Zroznicowanie cech jakosci tuszy tucznikow w zaleznosci od polimorfizmu genu hormonu wzrostu [GH-HaeII]. Acta Sci. Pol. Zootechnica. 9(2): 11-20.

Lan H, Liu H, Hong P, Li R, et al. (2018). Porcine growth hormone induces the nuclear localization of porcine growth hormone receptor in vivo. Asian-Australas. J. Anim. Sci. 31: 499-504. https://doi.org/10.5713/ajas.17.0585

Larsen NJ and Nielsen VH (1993). Apal and Cfo I polymorphisms in the porcine growth hormone gene. Anim. Genet. 24: 71. https://doi.org/10.1111/j.1365- 2052.1993.tb00928.x

Lyubov G, Kolosov A, Leonova M, Bakoev S, et al. (2016). Polymorphisms in several porcine genes are associated with growth traits. Am. J. Anim. Vet. Sci. 11: 136-141. http://doi:10.3844/ajavs 2016.136.141.

Overholt MF, Arkfeld EK, Mohrhauser DA, King DA, et al. (2016). Comparison of variability in pork carcass composition and quality between barrows and gilts. J. Anim. Sci. 94: 4415-4426. http://doi.10.2527/jas.2016- 0702.

Parr T, Mareko MHD, Ryan KJP, Hemmings KM, et al. (2016). The impact of growth promoters on muscle growth and the potential consequences for meat quality. Meat Sci. 120: 93-99. http://doi: 10.1016/j. meatsci.2016.04.022.

Pena RN, Ros-Freixedes R, Tor M and Estany J (2016). Genetic marker discovery in complex traits: a field example on fat content and composition in pigs. Int. J. Mol. Sci. 17: 2100. http://doi.org/10.3390/ ijms17122100.

Putnová L, Krenkovã L, Vrtkovã I, Dvorã KJ, et al. (2001). Association of the DdeI growth hormone gene polymorphism with some performance traits in Polish Large White and Czech Large White $\times$ Polish Large White pigs. J. Appl. Genet.42: 317-324.

Ramos EM and Gomide LAM (2007). Avaliação da qualidade de carnes: fundamentos e metodologias. Viçosa, MG: Editora UFV. 599p.

Ramos EM, Oliveira CPO, Matos RA and Santos DO (2009). Avaliação de características da carcaça e da qualidade da carne de queixada (Tayassu pecari [Link, 1795]). Ciênc. Agrotec. 33(spe): 1734-1740. doi.org/10.1590/S141370542009000700006

Rey-Salgueiro L, Martinez-Carballo E, Fajardo P, Chapela MJ, et al. (2018). Meat quality in relation to swine well-being after transport and during lairage at the slaughterhouse. Meat Sci. 142: 38-43. http://doi:10.1016/j.meatsci. 2018.04.005.

Rosenvald K and Andersen HJ (2003). Factors of significance for pork quality - a review. Meat Sci. 64: 219-237. http://doi.org/10.1016/S0309-1740(02)00186-9

Rübensam JM (2000). Transformações post mortem e qualidade de carne suína. In: Anais de Conferência Virtual Internacional Sobre Qualidade de Carne Suína, Via Internet. CNPSA/Embrapa. 12p.

Rybarczyk A, Kmieć M, Karamucki T and Arkadiusz T (2007). Association of growth hormone (GH) gene polymorphism with carcass and meat quality traits in PIC hybrid pigs. Arch. Tierzucht Special Issue. 50: 205-213.

Scheffler TL, Scheffler JM, Kasten SC, Sosnicki AA, et al. (2013). High glycolytic potential does not predict low ultimate pH in pork. Meat Sci. 95: 85-91. doi.org/10.1016/j.meatsci.2013.04.013.

Schellander K, Peli J, Kneissl F, Schmoll F, et al. (1994). Variation of the growth hormone gene in RYR 1 genotyped Austrian pig breeds. J. Anim. Breed. Genet. 111: 162- 166.

Song CY, Gao B, Jing RB, Tao Y, et al. (2003). Study on pig growth hormone gene polymorphisms in western meattype breeds and Chinese local breeds. J. Zhejiang Univ. Sci. 4: 734-739. http://doi:10.1631/jzus.2004.1621.

Tomovic VM, Zlender BA, Jokanović MR, Tomovic MS, et al. (2014). Technological quality and composition of the semimembranosus and M. longissimus dorsi from Large White and Landrace pigs. Agric. Food Sci. 23: 9-18.

Wang W, Huang L, Gao J, Ding NS, et al. (2003). Polymorphism of growth hormone gene in 12 pig breeds and its relationship with pig growth and carcass traits. Asian-Aust. J. Anim. Sci. 16: 161-164. https://doi.org/10.5713/ajas.2003.161.

Waters MJ, Hoang HN, Fairlie DP, Pelekanos RA, et al. (2006). New insights into growth hormone action. Mol. Endocrinol. 36: 1-7. http://doi:10.1677/jme.1.01933 